\title{
Short communication: Comparison of the effects of heat stress on milk and component yields and somatic cell score in Holstein and Jersey cows
}

\author{
D. L. Smith, T. Smith, B. J. Rude, and S. H. Ward ${ }^{1}$ \\ Department of Animal and Dairy Sciences, Mississippi State University, Mississippi State 39762
}

\section{ABSTRACT}

The objectives of this retrospective study were to (1) investigate the effects of heat stress (HS) climatic conditions and breed on milk and component yield for Holstein and Jersey cows on the same farm and (2) determine the effects of breed on udder health as measured by somatic cell score during HS climatic conditions. Data were collected from Dairy Herd Improvement Association records of 142 Jersey and 586 Holstein cows from the Bearden Dairy Research Center at Mississippi State University (Mississippi State). Heat stress climatic conditions were determined using a temperaturehumidity index (THI) to combine dry bulb temperature and relative humidity into one measure. Two analyses were conducted to determine the effects of HS. Heat stress was defined as THI $\geq 72$, and reported as HS+ for the first analysis and HS for the second analysis. The first analysis compared breeds during HS+ and non-heat-stress (HS-) conditions. Holstein milk yield decreased during HS+, whereas Jersey milk yield increased. Milk fat percentage for Holstein and Jersey cows declined during HS+. Holstein fat-corrected milk yield decreased during HS+, whereas Jersey fat-corrected milk yield during $\mathrm{HS}+$ did not differ from that during HS-. During HS+, somatic cell score increased in milk from Holstein and Jersey cows compared with HS-. In the second analysis, HS was categorized as mild, moderate, or severe. The corresponding THI values were THI $\geq 72$ but $<79$, THI $\geq 79$ but $<90$, and THI $\geq 90$. Holstein milk yield declined during moderate and severe HS, whereas Jersey milk yield declined during severe HS. Holstein milk fat percentage was less during moderate and severe HS compared with milk fat percentage during mild HS. Jersey milk fat percentage did not differ with regard to HS category. Jersey cows appeared to be more heat tolerant than Holstein cows; however, Holstein cows still produced larger volumes of milk.

Key words: dairy cow, milk production, heat stress

Received May 15, 2012.

Accepted January 2, 2013.

${ }^{1}$ Corresponding author: srhill@ads.msstate.edu

\section{Short Communication}

Selection over time for milk-producing traits, whether total yield or nutrients, may have resulted in the decrease of some fitness traits, which are less heritable. As breeders selected for greater milk production, they may have inadvertently also selected for cows with less heat tolerance. High external temperatures decrease the ability of the cow to adequately dissipate body heat and to properly regulate internal body temperature (Finch, 1986). As body temperature rises the cow enters heat stress (HS) and is forced to make changes in physiological processes, such as milk production and immune function, to decrease internal heat production (Kadzere et al., 2002). Seasonal production losses due to HS and increases in SCS during summer months are recurring challenges for many dairy producers.

Early research suggests that the Jersey breed may be more heat tolerant than the Holstein breed with respect to milk yield (Seath and Miller, 1947; Harris et al., 1960; Collier et al., 1981). However, the relationship between breed and response to HS has not been robustly established in modern dairy cattle. In a recent review of the effects of dairy breed on feed efficiency, Grainger and Goddard (2004) highlighted the paucity of research data on the effect of breed. Other recent comparisons of Jersey and Holstein cattle exist (Muller and Botha, 1998; Garcia-Peniche et al., 2006; Heins et al., 2008). None of these have used lactating cows to directly compare the effects of HS on milk yield, components, and SCS. Discovering any difference among dairy breeds for heat tolerance will allow dairy producers in climates prone to HS to select the most suitable cattle for successful production.

Investigations into breed differences of Holstein and Jersey cattle have produced mixed results as to which breed is most heat tolerant. One breed comparison of body temperature and BCS reported no breed differences of mean or maximum body temperature or BCS (Kendall and Webster, 2009). The mean body temperature in the summer tended to be greater and the daily minimum body temperature of lactating Jersey cows was greater than that of Holstein-Friesian and HolsteinFriesian $\times$ Jersey cows, with no difference between 
breeds during any other measurement period (Kendall and Webster, 2009). West (2003) reported a decline in milk yield by Holsteins that was more rapid than for Jerseys across a range of temperature-humidity indices (THI) from 72 to 84 . Jerseys had a tendency to have cooler rectal temperatures across the same range of THI, with Holsteins having $0.3^{\circ} \mathrm{C}$ greater body temperature than Jerseys (West, 2003). Rectal temperature response to black globe temperature (temperature without effects of sun radiation) differed by breed, with rectal temperature of Jersey cows always being less than Holstein cows (Collier et al., 1981).

Studies that investigated the effect of season on bulk tank SCS had varied results. In one study, cows with SCC $<200,000$ had peak SCC in the months of May and August, whereas cows with SCC >200,000 had peak SCC in May and July (Lievaart et al., 2007). Another study found that mean bulk tank SCS was greatest in September and lowest in March (Olde Riekerink et al., 2007; El-Tahawy and El-Far, 2010). El-Tahawy and El-Far (2010) found that SCS was greatest during the autumn and winter. Attempts to reproduce the seasonal increase in SCS by putting cows in environmentally controlled chambers and increasing the temperature have not been successful (Dohoo and Meek, 1982), thus further clouding the understanding of the relationship between HS and SCS.

One explanation for the inconsistent research findings could be that the increased SCS during summer months is not entirely the result of temperature. The freestall environment during the summer may comprise ideal conditions for pathogen proliferation. Seasonal increases in SCS may be the result of increased pathogen exposure and contamination, due to the natural increase in pathogen load (Reneau, 1986). Summer increases in SCS may also be due, in part, to the decreased milk production that is observed during HS. Heat stress may also have deleterious effects on the immune system of the cow. One study found that periods of intense prolonged HS were associated with decreased cellular immunity, enhanced humoral response, and greater concentrations of plasma cortisol (Lacetera et al., 2005). Although the specific relationship between HS and SCS is not clear, the possibility exists that one breed may be more resistant to increased SCS during periods of HS. If such a difference does exist, it will offer dairy producers one more tactic for meeting the new SCC certification requirements announced by the US Department of Agriculture in November 2011 (Lewis, 2011).

One of the major sources of variation in studies of dairy cows comes from differences in management. Accordingly, data was collected on one farm to minimize management bias and differences of pathogen load. The objective of this retrospective study was to investigate effect of HS and breed on milk and component yield for Holstein and Jersey cows on the same farm. A second objective was to determine the effects of breed on udder health as measured by SCS during times of HS.

Data were collected from $\mathrm{DHI}(\mathrm{A})$ records of 142 Jersey and 586 Holstein cows from the Bearden Dairy Research Center at Mississippi State University (Mississippi State). After the removal of duplicate records, a total of 16,429 individual monthly records, dating from 1997 to 2010, were used. There were 3,442 records from 142 Jersey cows that averaged 190 DIM and 12,698 records from 586 Holstein cows that averaged 205 DIM. Measures used from the monthly records were milk yield, milk fat percentage, milk protein percentage, and SCS. Fat-corrected milk was derived from milk yield and milk fat percentage using the following equation (Gaines, 1928):

$$
\mathrm{FCM}=(0.4 \times \text { milk yield })+(15 \times \text { fat yield }) .
$$

Climate data associated with dates before April 21, 2002, were obtained from the National Weather Service station located at the Golden Triangle Regional Airport, approximately $16 \mathrm{~km}$ northeast of the dairy. Climate data associated with dates after April 21, 2002, were obtained from the weather station operated by the Department of Geosciences on the campus of Mississippi State University, approximately $9 \mathrm{~km}$ northwest of the dairy. There were less than 10 test dates for which data was not available from either station. For those dates, climate data was obtained from the National Weather Service station located at the Columbus Air Force base near Columbus, Mississippi. Climate data included daily maximums and minimums for temperature and relative humidity.

Maximum and minimum ambient temperature and relative humidity were determined from hourly data for each 24-h period and were used to calculate THI (West, 2003). The equation used for THI was as follows:

$$
\mathrm{THI}=\mathrm{td}-(0.55-0.55 \mathrm{RH})(\mathrm{td}-58),
$$

where td is the dry bulb temperature in ${ }^{\circ} \mathrm{F}$ and $\mathrm{RH}$ is relative humidity expressed as a decimal. The average THI for the $3 \mathrm{~d}$ preceding the test date was calculated and assigned to each test-day record (Bohmanova et al., 2008).

Cows were housed in 2 freestall barns at the Bearden Dairy Research Center. Both Jersey and Holstein cows were housed in both barns and cows were grouped as fresh, primiparous, or multiparous. All cows were fed the same TMR at approximately $4.0 \%$ of average 
BW, with the exception of fresh cows who received a transition TMR (nutrient analysis was not available). Freestalls were bedded with sand and cleaned and leveled twice daily. The barns were equipped with fans and sprinklers that were manually switched on when cows demonstrated signs of HS. The fans were located over the feed bunk and over the stalls, whereas the sprinklers were located over the feed bunk only. During the spring and fall, fans were turned on during the day when the temperature was greater than $23.8^{\circ} \mathrm{C}$ and turned off at night. During the summer months (typically May 15 to September 1), the fans operated continually. Sprinklers were managed similar to the fans. Cows were milked twice daily at approximately 0400 and $1500 \mathrm{~h}$. All lactating cows were fed the same TMR twice daily.

Effects of THI, breed, and the interaction were analyzed using PROC MIXED (SAS Institute, 2009). The dependent variables were test-day milk yield and milk components, SCS, and FCM. The model used included fixed effects for THI (t), breed (b), and $\mathrm{b} \times \mathrm{THI}$, with DIM (d) as a covariate. All main effects were tested along with all interactions. Two analyses were conducted. In the first analysis, HS was defined as THI $\geq 72$ (HS+), and no HS (HS-) was defined as THI $<72$ (Bohmanova et al., 2008). In the second analysis, HS was categorized as mild, moderate, or severe (Armstrong, 1994). The corresponding THI values were 72 $\leq$ THI $<79,79 \leq$ THI $<90$, and $90 \leq$ THI. The final model was as follows:

$$
\mathrm{Y}_{\mathrm{ijk}}=\mu+\mathrm{t}_{\mathrm{i}}+\mathrm{b}_{\mathrm{j}}+\mathrm{tb}_{\mathrm{ij}}+\mathrm{d}_{\mathrm{k}}+\mathrm{e}_{\mathrm{ijk}},
$$

where $Y_{\mathrm{ijk}}=$ test-day milk yield, FCM, or test-day SCS of the ith THI, the jth breed, and kth DIM, $\mu$ is the population mean, and $e_{i j k}$ is the residual error. Results are reported as least squares means, and means were considered to differ when $P \leq 0.05$.
The first analysis compared breeds during HS+ and HS - conditions. During both HS+ and HS-, breed had an effect on yield, with Holstein cows having greater yield than Jersey cows $(P<0.01$; Table 1$)$. Holstein milk yield decreased in HS+ from 35.6 to 34.2 $\mathrm{kg} / \mathrm{d}$, whereas Jersey milk yield increased from 25.9 $\mathrm{kg} / \mathrm{d}$ to $26.6 \mathrm{~kg} / \mathrm{d}(P<0.01$; Table 1$)$. This is similar to results of others who noted a decrease in milk yield when Holstein cows experienced a THI from 70 to 80 (Sharma et al., 1983; Silanikove et al., 2009; Zimbelman et al., 2009). The increase in yield for Jersey cows are in contrast to others who reported a decrease in yield for Jersey cows in HS (West et al., 2003; Bryant et al., 2007). One difference in the current study and those that found a decrease in yield for Jersey cows may be in the operation and effects of heat abatement equipment. Results of the second analysis show the effects of mild, moderate, and severe HS. Holstein milk yield decreased from 34.8 to $32.9 \mathrm{~kg} / \mathrm{d}$ in moderate HS and decreased further to $30.4 \mathrm{~kg} / \mathrm{d}$ in severe HS $(P<0.01$; Table 2 ). Jersey milk yield was not different in moderate HS $(P<0.10)$ and significantly decreased to $23.8 \mathrm{~kg} / \mathrm{d}$ in severe HS $(P<0.01$; Table 2$)$. It appears from these results that the increase in Jersey milk yield seen in the first analysis show Jersey cows being less susceptible to mild HS than Holstein cows. The results of the second analysis did confirm research done by others (Bouraoui et al., 2002; West et al., 2003; Spiers et al., 2004) that indicated decreased milk yield associated with increased THI.

Milk fat percentage increased in $\mathrm{HS}+$ for Holstein cows and was not different for Jersey cows $(P<0.01$; Table 1). Results of previous studies found that HS either did not have an effect (Wheelock et al., 2010) or increased milk fat percentage (Sharma et al., 1983; Bouraoui et al., 2002). Several factors such as stage of lactation and diet, as well as heat abatement could account for the unusual increase in milk fat percentage

Table 1. Milk yield, milk components, SCS, and FCM of Holstein and Jersey cattle under the same management conditions during heat-stress (HS+) and non-heat-stress (HS-) conditions measured with temperature humidity index (THI)

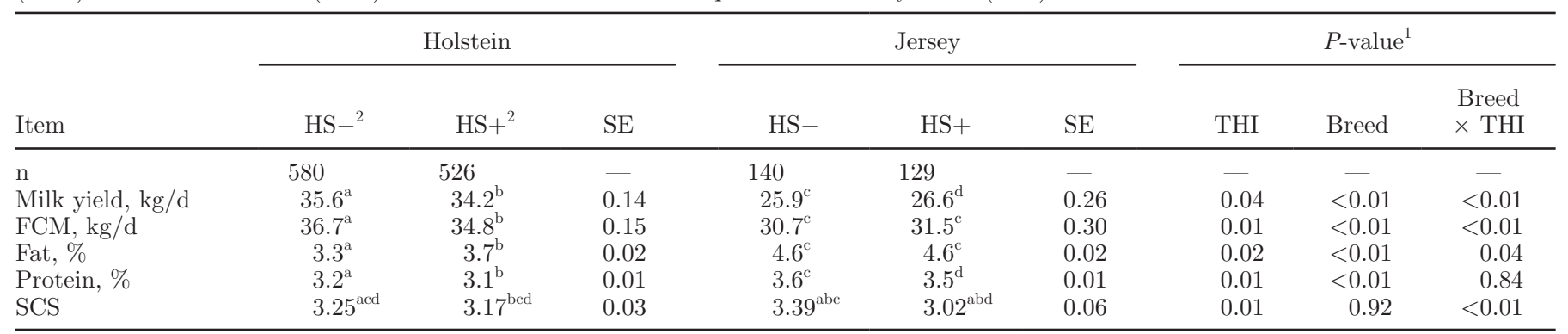

${ }^{\mathrm{a}-\mathrm{d}}$ Within rows, values with different superscripts are significantly different $(P<0.05)$.

${ }^{1}$ THI $P$-value $=$ main effect of THI; breed $P$-value $=$ main effect of breed; breed $\times$ THI $P$-value $=$ interaction of breed and THI

${ }^{2} \mathrm{HS}-$ was defined as THI $<68$, and HS+ was defined as THI $>68$. 
Table 2. Milk yield, milk components, SCS, and FCM of Holstein and Jersey cows under the same management conditions during mild, moderate, and severe environmental heat stress (HS) measured with temperature humidity index (THI) ${ }^{1}$

\begin{tabular}{|c|c|c|c|c|c|c|c|c|c|c|c|}
\hline \multirow[b]{2}{*}{ Item } & \multicolumn{4}{|c|}{ Holstein } & \multicolumn{4}{|c|}{ Jersey } & \multicolumn{3}{|c|}{$P$-value ${ }^{2}$} \\
\hline & $\begin{array}{c}\text { Mild } \\
\text { HS }\end{array}$ & $\begin{array}{c}\text { Moderate } \\
\text { HS }\end{array}$ & $\begin{array}{c}\text { Severe } \\
\text { HS }\end{array}$ & $\mathrm{SE}$ & $\begin{array}{l}\text { Mild } \\
\text { HS }\end{array}$ & $\begin{array}{c}\text { Moderate } \\
\text { HS }\end{array}$ & $\begin{array}{c}\text { Severe } \\
\text { HS }\end{array}$ & $\mathrm{SE}$ & THI & Breed & $\begin{array}{l}\text { Breed } \\
\times \text { THI }\end{array}$ \\
\hline $\mathrm{n}$ & 262 & 506 & 358 & - & 78 & 121 & 79 & - & - & - & - \\
\hline Milk yield, $\mathrm{kg} / \mathrm{d}$ & $34.8^{\mathrm{a}}$ & $32.9^{\mathrm{b}}$ & $30.4^{\mathrm{c}}$ & 0.51 & $27.1^{\text {de }}$ & $25.7^{\mathrm{de}}$ & $23.8^{\mathrm{f}}$ & 0.93 & $<0.01$ & $<0.01$ & 0.62 \\
\hline $\mathrm{FCM}, \mathrm{kg} / \mathrm{d}$ & $34.2^{\text {abd }}$ & $33.7^{\text {abd }}$ & $31.1^{\text {cde }}$ & 0.59 & $32.0^{\text {abcde }}$ & $30.8^{\mathrm{dec}}$ & $28.4^{\mathrm{f}}$ & 1.07 & $<0.01$ & $<0.01$ & 0.86 \\
\hline Fat, $\%$ & $3.5^{\mathrm{a}}$ & $3.7^{\mathrm{bc}}$ & $3.7^{\mathrm{bc}}$ & 0.06 & $4.6^{\text {def }}$ & $4.7^{\mathrm{def}}$ & $4.6^{\mathrm{def}}$ & 0.10 & $<0.05$ & $<0.01$ & 0.20 \\
\hline
\end{tabular}

seen in the current study. Unfortunately, records of diet composition for the entire time period of this study were not available.

Breed was found to have an effect on milk fat percentage, with Jersey cows having greater milk fat percentage than Holstein cows $(P<0.01$; Table 2$)$. Milk from Jersey cows did not differ in regard to milk fat percentage in mild, moderate, or severe HS. In moderate HS, milk fat percentage in milk from Holstein cows increased from 3.5 to $3.7 \%(P<0.01$; Table 2$)$. Milk fat percentage in milk from Holstein cows in moderate HS did not differ from milk fat percentage in milk from Holstein cows in severe HS.

During both HS+ and HS- conditions, Holstein cows had greater FCM than Jersey cows $(P<0.01$; Table 1). During $\mathrm{HS}+$, FCM from Holstein cows decreased from 36.7 to $34.8 \mathrm{~kg}(P<0.01)$. The decrease in FCM for Holstein cows is not unexpected, considering the decrease in both yield and milk fat percentage seen in $\mathrm{HS}+$. Jersey cows increased in FCM during $\mathrm{HS}+$ from 30.7 to $31.5 \mathrm{~kg} / \mathrm{d}(P<0.01$; Table 1$)$.

Breed was found to have an effect on FCM $(P<0.01$; Table 2). Holstein and Jersey FCM in mild HS did not differ from FCM in moderate HS $(P>0.05)$. Holstein FCM decreased in severe HS from 33.7 to $31.1 \mathrm{~kg} / \mathrm{d}$ $(P<0.01)$. As with Holstein FCM, Jersey FCM also decreased in severe HS from 30.8 to $28.4 \mathrm{~kg} / \mathrm{d}(P<$ 0.01 ; Table 2). When the changes in milk yield and milk fat percentage in cows in HS are taken into account, the differences in FCM during HS between and within breed are likely explained by more than one mediating variable.

Milk protein percentage declined in Holstein cows during HS+ from 3.2 to $3.1 \%$ and from 3.6 to $3.5 \%$ for Jersey cows $(P<0.01$; Table 1$)$. Milk protein percentage in milk from Jersey cows decreased in moderate HS from 3.7 to $3.6 \%(P<0.01$; Table 2$)$. Milk protein percentage from Holstein cows decreased in moderate
HS from 3.2 to $3.1 \%(P<0.01$; Table 2$)$. In milk from Holstein cows, the milk protein percentage increased from 3.1 to $3.2 \%$ during severe HS $(P<0.01$; Table 1$)$. Literature dealing with the effects of HS on milk protein percentage is indeterminate. Bouraoui et al. (2002) and Sharma et al. (1983) reported a decrease in protein percentage, whereas Wheelock et al. (2010) reported no difference. As with FCM, the effects of HS on milk protein percentage are likely mediated by several variables that have yet to be fully investigated.

During HS+ and HS-, SCS of milk from Holstein cows was not different from SCS of milk from Jersey cows $(P<0.90$; Table 1$)$. Milk from Holstein cows had a decrease in SCS during HS+ from 3.25 to $3.17(P$ $<0.01$; Table 1). Milk from Jersey cows also had a decrease of SCS during HS+ from 3.39 to $3.02(P<$ 0.01; Table 1). Milk from Holstein cows did not differ with respect to SCS in mild and moderate HS, with SCS being 4.18 in both categories $(P<0.98$; Table 2$)$. Milk from Holstein cows had decreased SCS from 4.18 to 3.84 during severe HS $(P<0.01$; Table 2$)$. Somatic cell score of milk from Jersey cows increased during moderate HS from 3.61 during mild HS to 4.10 during moderate HS $(P<0.02$; Table 2$)$. Milk from Jersey cows had decreased SCS from 4.10 during moderate HS to 3.31 during severe HS $(P<0.01$; Table 2$)$. This data suggests that no difference exists in SCS between Jersey and Holstein breeds. These results are counter to anecdotal and some scientific evidence that greater THI leads to greater SCS. One reason that data of Jersey cows from this study may not agree with data from previous SCS research is that most studies of SCS have been done with only Holstein cows or breeds were not separated (Table 3).

Jersey cows used in this study were apparently more heat tolerant than Holstein cows. The increased milk production of Jersey cows during HS compared with the decreased milk production of Holstein cows during 
Table 3. Differences of the means for milk yield, FCM, milk protein, milk fat, and SCS of Holstein and Jersey cattle under the same management conditions during heat-stress (HS+) and non-heat-stress (HS-) conditions measured with temperature humidity index (THI)

\begin{tabular}{|c|c|c|c|c|c|c|c|c|c|c|c|}
\hline Holstein & Jersey & $\begin{array}{l}\text { Milk yield, } \\
\mathrm{kg} / \mathrm{d}\end{array}$ & $P$-value & $\begin{array}{l}\mathrm{FCM}, \\
\mathrm{kg} / \mathrm{d}\end{array}$ & $P$-value & Milk protein, & $P$-value & $\begin{array}{c}\text { Milk fat, } \\
\%\end{array}$ & $P$-value & SCS & $P$-value \\
\hline $\mathrm{HS}+$ & $\mathrm{HS}+$ & 7.48 & $<0.01$ & 3.35 & $<0.01$ & -0.48 & $<0.01$ & -0.97 & $<0.01$ & 0.15 & 0.02 \\
\hline HS- & $\mathrm{HS}-$ & 9.66 & $<0.01$ & 6.03 & $<0.01$ & -0.49 & $<0.01$ & -0.88 & $<0.01$ & -0.14 & $<0.01$ \\
\hline
\end{tabular}

HS is not enough to overcome the overwhelming difference of total milk yield between the 2 breeds. Breed differences did exist; however, those differences may not have been as a result of response to HS but simply a difference in production between breeds. When comparing results of this study to previous HS research, heat abatement does appear to have a dramatic effect for the response of cows to HS.

Future research should focus on comparing feed efficiency during HS between breeds. Although Holstein cows have an advantage over Jersey cows for total milk yield, Jersey cows may have an advantage for improved feed efficiency. The effects of HS on milk fat and protein percentages reported in this and other HS studies appear to be mediated by several variables. Identifying and understanding those variables and their mediating effects in the relationship of HS and milk components may help to explain the discrepant results in studies to date. Data from this study indicates that SCS and THI may have a curvilinear relationship. This may lead to a reduced SCS but may not lead to decreased clinical cases of mastitis. Further research is needed to ascertain whether hot THI conditions have deleterious effects on microorganisms that cause mastitis. Furthermore, research is needed to determine if cows have an increase in clinical mastitis cases after experiencing severe HS+ and what appears to be reduced immune response. This study, as with previous studies, found that the relationship of SCS with climate is complex.

\section{REFERENCES}

Armstrong, D. V. 1994. Heat stress interaction with shade and cooling. J. Dairy Sci. 77:2044-2050.

Bohmanova, J., I. Misztal, S. Tsuruta, H. D. Norman, and T. J. Lawlor. 2008. Short communication: Genotype by environment interaction due to heat stress. J. Dairy Sci. 91:840-846.

Bouraoui, R., M. Lahmar, A. Majdoub, M. Djemali, and R. Belyea. 2002. The relationship of temperature-humidity index with milk production of dairy cows in a Mediterranean climate. Anim. Res. 51:479-491.

Bryant, J. R., N. López-Villalobos, J. E. Pryce, C. W. Holmes, and D. L. Johnson. 2007. Quantifying the effect of thermal environment on production traits in three breeds of dairy cattle in New Zealand. N. Z. J. Agric. Res. 50:327-338.

Collier, R. J., R. M. Eley, A. K. Sharma, R. M. Pereira, and D. E. Buffington. 1981. Shade management in subtropical environment for milk yield and composition in Holstein and Jersey cows. J. Dairy Sci. 64:844-849.
Dohoo, I. R., and A. H. Meek. 1982. Somatic cell counts in bovine milk. Can. Vet. J. 23:119-125.

El-Tahawy, A. S., and A. H. El-Far. 2010. Influences of somatic cell count on milk composition and dairy farm profitability. Int. J. Dairy Technol. 63:463-469.

Finch, V. A. 1986. Body temperature in beef cattle: Its control and relevance to production in the tropics. J. Anim. Sci. 62:531-542.

Gaines, W. L. 1928. An efficiency formula for dairy cows. Science 67:353-354

Garcia-Peniche, T. B., B. G. Cassell, and I. Misztal. 2006. Effects of breed and region on longevity traits through five years of age in Brown Swiss, Holstein, and Jersey cows in the United States. J. Dairy Sci. 89:3672-3680.

Grainger, C., and M. E. Goddard. 2004. A review of the effects of dairy breed on feed conversion efficiency-An opportunity lost? Anim. Prod. Aust. 25:77-80.

Harris, D. L., R. R. Shrode, I. W. Rupel, and R. E. Leighton. 1960. A study of solar radiation as related to physiological and production responses of lactating Holstein and Jersey cows. J. Dairy Sci. 43:1255-1262

Heins, B. J., L. B. Hansen, A. J. Seykora, A. R. Hazel, D. G. Johnson and J. G. Linn. 2008. Crossbreds of Jersey $\times$ Holstein compared with pure Holsteins for body weight, body condition score, dry matter intake, and feed efficiency during the first one hundred fifty days of first lactation. J. Dairy Sci. 91:3716-3722.

Kadzere, C. T., M. R. Murphy, N. Silanikove, and E. Maltz. 2002 Heat stress in lactating dairy cows: A review. Livest. Prod. Sci 77:59-91.

Kendall, P. E., and J. R. Webster. 2009. Season and physiological status affects the circadian body temperature rhythm of dairy cows. Livest. Sci. 125:155-160.

Lacetera, N., U. Bernabucci, D. Scalia, B. Ronchi, G. Kuzminsky, and A. Nardone. 2005. Lymphocyte functions in dairy cows in hot environment. Int. J. Biometeorol. 50:105-110.

Lewis, D. 2011. European Union Health Certification Program. Agricultural Marketing Service, United States Department of Agriculture, Washington, DC.

Lievaart, J. J., H. W. Barkema, W. D. J. Kremer, J. van den Broek, J. H. M. Verheijden, and J. A. P. Heesterbeek. 2007. Effect of herd characteristics, management practices, and season on different categories of the herd somatic cell count. J. Dairy Sci. 90:4137-4144.

Muller, C. J. C., and J. A. Botha. 1998. The comparative performance of primiparous Holstein Friesland and Jersey cows on complete diets during summer in a temperate climate. S. Afr. J. Anim. Sci $28: 161-166$

Olde Riekerink, R. G., H. W. Barkema, and H. Stryhn. 2007. The effect of season on somatic cell count and the incidence of clinical mastitis. J. Dairy Sci. 90:1704-1715.

Reneau, J. K. 1986. Effective use of dairy herd improvement somatic cell counts in mastitis control. J. Dairy Sci. 69:1708-1720.

SAS Institute. 2009. SAS OnlineDoc. Version 9.2. SAS Institute Inc. Cary, NC.

Seath, D. M., and G. D. Miller. 1947. Heat tolerance comparisons between Jersey and Holstein cows. J. Anim. Sci. 6:24-34.

Sharma, A. K., L. A. Rodriguez, G. Mekonnen, C. J. Wilcox, K. C. Bachman, and R. J. Collier. 1983. Climatological and genetic effects on milk composition and yield. J. Dairy Sci. 66:119-126.

Silanikove, N., F. Shapiro, and D. Shinder. 2009. Acute heat stress brings down milk secretion in dairy cows by up-regulating the 
activity of the milk-borne negative feedback regulatory system. BMC Physiol. 9:13.

Spiers, D. E., J. N. Spain, J. D. Sampson, and R. P. Rhoads. 2004. Use of physiological parameters to predict milk yield and feed intake in heat-stressed dairy cows. J. Therm. Biol. 29:759-764.

West, J. W. 2003. Effects of heat-stress on production in dairy cattle. J. Dairy Sci. 86:2131-2144.

West, J. W., B. G. Mullinix, and J. K. Bernard. 2003. Effects of hot, humid weather on milk temperature, dry matter intake, and milk yield of lactating dairy cows. J. Dairy Sci. 86:232-242.
Wheelock, J. B., R. P. Rhoads, M. J. VanBaale, S. R. Sanders, and L. H. Baumgard. 2010. Effects of heat stress on energetic metabolism in lactating Holstein cows. J. Dairy Sci. 93:644-655.

Zimbelman, R., R. Rhoads, M. Rhoads, G. Duff, L. Baumgard, and R. Collier. 2009. A re-evaluation of the impact of temperature humidity index (THI) and black globe humidity index (BGHI) on milk production in high producing dairy cows. Pages 158-169 in Proc. Southwest Nutr. Conf. R. J. Collier, ed. 